\title{
IMPLICATIONS OF ICT FOR DEVELOPMENT ON ENHANCING RURAL ENTREPRENEUR PROGRAM (REP) AT TELECENTRES IN MALAYSIA
}

\author{
Marhaini Mohd Noor* \\ Universiti Malaysia Terengganu \\ Noreha Hashim \\ Universiti Malaysia Terengganu \\ Rahaya Md. Jamin \\ Universiti Malaysia Terengganu
}

\begin{abstract}
This paper examines rural social entrepreneurship program in rural Malaysia communities. The program seeks to promote and turn rural entrepreneurs into social entrepreneurs by strengthening their economic activities and enhancing social capital. This paper focuses on a component of the rural entrepreneur program (REP), namely the Social Entrepreneur Club (SEC). The club runs the rural entrepreneur program and upholds the program's objectives. It promotes the socialization of rural communities by engaging them in entrepreneurial activities. The club operates under the Rural Internet Centre (RIC); a telecentre that provides space for rural communities to enhance their ICT knowledge and skills. However, despite the opportunity provided, some of the rural entrepreneurs do not show adequate interest in the program as they prefer being entrepreneurs, but not social entrepreneurs. Thus, the success of the SECs depends on the entrepreneurs' participation in the program, the geographical locations and the support from the telecentre managers. This paper employs the economic gardening concept and community informatics approach to empirically gather evidence to test the theory on ICT for development; particularly rural development for rural communities. A quantitative method has been used to measure the implications of ICT in this program. Data from the entrepreneurs is obtained through an online survey which has been conducted across the varying regions in Malaysia. The quantitative data is supported by interviews (qualitative method) with telecentre managers. The primary data has been triangulated to analyze the results. The key findings show that the SEC is seen as economic development strategy by creating jobs, as well as increasing income and business opportunities. It also strengthens social networking needed to build social capital within and outside of the rural communities. Hence SEC is also a community connector and can be used as an indicator on the quality of rural communities' wellbeing.
\end{abstract}

Keywords: Social entrepreneur club; Rural entrepreneur program; Rural internet centre; Community informatics and social capital.

Received:16 January 2018

Accepted:20 May 2020

\footnotetext{
- Corresponding author: Marhaini Mohd Noor Faculty of Maritime Studies, Universiti Malaysia Terengganu (UMT), 21030 Kuala Nerus, Terengganu, Malaysia. Emel: marhaini.noor@umt.edu.my
} 


\section{INTRODUCTION}

The rural social entrepreneurship program is targeted at local entrepreneurs in rural areas of Malaysia as a means of strengthening their economic activities and enhancing social capital. The focus is on Social Entrepreneur Club (SEC) adoption and implementation at the Rural Internet Centres (RICs) in Malaysia. The RIC is established in 2000 as a telecentre and a platform for rural communities to improve their ICT knowledge and skills. By 2006, 42 RICs had been established in 13 states in the country (MEWC, 2006). Responsibility for the project is shared between the Ministry of Energy, Water and Communications, Malaysia Post Berhad and Warisan Global (WG) (a private company). The RICs's ICT infrastructure could provide economies of scale to stimulate network building and consequent spill-over benefits. Furthermore, the RICs also provide access to ICT which might lead to education, employment and business opportunities. RICs also provide a link between ICT growth and economic growth that benefits the poor. Therefore, the RICs play an important role in enabling the rural poor to gain as many ICT benefits as possible. The major institutional stakeholder is the Ministry of Information, Communication and Culture of Malaysia (previously, the responsible ministry was the Ministry of Energy, Water and Communications). The MICC is the driver of the RIC program. In the first phase, the MICC's primary objective was to achieve basic ICT literacy among targeted groups in rural communities. The second phase was to improve the rural communities' income by introducing and implementing Social Entrepreneurs Clubs (SECs) at each RIC. These SECs would encourage the development of local businesses which would then hopefully increase local income and employment. The third phase was for the RICs to become sustainable and independent. From 2012 until now, the Ministry of Communications and Multimedia Malaysia (MCMM) has been responsible for RICs and all of the programs are monitored by MCMM.

The focus of the current research for RIC and SEC is on the enhancement of the centres' broadband speeds. Malaysian Communications and Multimedia Deputy Minister has also stated that RIC's functions and services would also be improved according to the needs of the local community. A total of 42 RICs have been established throughout the country since 2004 to facilitate information access to rural people (FOMCA, 2019). More workshops on e-entrepreneurship have been conducted by all 42 RICs to generate more local entrepreneurs. The vision for RIC 2019 is to empower the digital community towards socio-economic improvement and for RIC to become a digital one-stop centre (MCMM, 2019).

The main objectives of this research and the program are (1) to enhance awareness of the SECs among local entrepreneurs, particularly the SEC members, (2) to build capacity and foster economic growth in rural communities by encouraging rural entrepreneurs' economic activities and innovations, and (3) to strengthen social capital amongst rural entrepreneurs based on the community informatics approach/theory, as well as proposing policy recommendations and a review of relevant literature and theories. Hence the research questions are (1) How aware are SEC users of the SEC programs? (2) Does the community perceive an increase in building capacity and economic growth? (3) Does the community perceive an increase in social capital amongst rural entrepreneurs?

This entrepreneurial strategy is adopted to facilitate innovation by local entrepreneurs in rural Malaysia; and is implemented through the SEC and is grounded in a community informatics theory of rural study area. Thus, it is envisioned that the SEC connects and builds collaboration with local 
entrepreneurs and beyond. This is because it has the potential to promote economic vitality for rural growth and community development. Moreover, ICT's potential for promoting development can be ascertained through a study on the SEC's ability to transform rural communities into active participants in a knowledge society.

The community informatics (CI) approach is community based, and provides legitimacy for community development, community action as well as service provision through established agencies. The social inclusion agenda that is fundamental to a CI approach is based on the principles of participation, self-actualisation and individual responsibilities to the community as a whole. It puts potentials of $\mathrm{CI}$ at the centre of not only new forms of community representation, but also community participation. This study empirically contributes to research on rural development and, in particular, advances on empirical studies of building social capital (as one of the dimensions in this study) through community informatics. Therefore, the dimensions used to measure the outcome of this research are social capital (bonding capital, bridging capital and local community association), job opportunity, business opportunity and quality of life

\subsection{Rural Entrepreneur Program (REP) - Social Entrepreneurs Club (SEC)}

\subsubsection{Social Entrepreneurs Club (SEC)}

The SEC was first established in 2008, and every RIC has been introduced to champion the concept of social entrepreneurship. Training on entrepreneurship is provided by Warisan Global through several series of training on capacity building. The RIC is trained to make RIC sustainable and SEC as one of the initiatives for sustainability. Each RIC is required to set up the SEC as an effort to assist and create new entrepreneurs among the locals. In this context, RIC managers are considered as motivators and facilitators to the creation of new entrepreneurs. The RIC is required to liaise with government agencies such as MARA, FAMA, MARDI, Animal Department and other entities for information to be channelled to the community.

A sub-goal of the RIC program is to develop the capability and capacity of local entrepreneurs in rural Malaysia communities. The Social Entrepreneurs Club in the RIC program (abbreviated as SEC but better known as KUSPID) is a club owned by each local rural community and operated under the RIC program with its own committee. This becomes a platform for grassroots entrepreneurs where they can share knowledge, experiences, learn about trading by marketing their products through the Internet and connecting to other communities. Hence by 2010 , there were more than 2,000 SEC members at the 42 RICs nationwide (MRRD, 2010). Table 1 summarizes the functions and purposes of SEC as part of the human capacity building focus of the RIC program.

Table 1: Summary of SEC (Entrepreneurial Program)

\begin{tabular}{ll}
\hline \hline \multicolumn{1}{c}{ Functions and purposes } & \multicolumn{1}{c}{ Descriptions } \\
\hline $\begin{array}{l}\text { 1) Involve SEC business operations } \\
\text { and sustainability }\end{array}$ & $\begin{array}{l}\text { To involve SEC as a business operation and as a } \\
\text { club that can contribute to the sustainability of } \\
\text { RICs. }\end{array}$
\end{tabular}




\begin{tabular}{ll}
\hline \hline \multicolumn{1}{c}{ Functions and purposes } & \multicolumn{1}{c}{ Descriptions } \\
\hline $\begin{array}{l}\text { 2) Build strong committees and } \\
\text { participation }\end{array}$ & $\begin{array}{l}\text { To establish strong management committees and } \\
\text { encourage them to participate in SEC program. }\end{array}$ \\
\hline $\begin{array}{l}\text { 3) Creative managers to attract } \\
\text { Community participation }\end{array}$ & $\begin{array}{l}\text { To recruit more creative RIC managers so as to } \\
\text { promote and attract more local } \\
\text { communities to join SEC. }\end{array}$ \\
\hline $\begin{array}{l}\text { 4) Job opportunity, business and } \\
\text { social networking }\end{array}$ & $\begin{array}{l}\text { To create job opportunity, business and social } \\
\text { networking for the entrepreneurs or SEC } \\
\text { members. }\end{array}$ \\
\hline $\begin{array}{l}\text { 5) SEC as an indicator of the increase in } \\
\text { the quality of rural life and a community } \\
\text { connector }\end{array}$ & $\begin{array}{l}\text { To develop SEC in the long term that can } \\
\text { contribute to an improvement in QoRL and SEC } \\
\text { as a community connector. }\end{array}$ \\
\hline \hline
\end{tabular}

It is important to note that the SEC has been established as a means to encourage rural communities to get involved in social entrepreneurship, and for existing entrepreneurs to socialise with other entrepreneurs in other rural communities. The SEC conducts business operations that contribute to RIC's sustainability. In addition, the SEC also needs to establish strong committees and encourage their participation in the program (Marhaini, 2010). As a consequence, there is a need to recruit more creative RIC managers so as to promote and encourage local rural communities to join the SEC. Thus, the SEC is seen as a means to create jobs and business opportunities, as well as promoting social networking in the rural communities associated with each RIC. The SEC is also seen as an entity which is effective in connecting the local rural community with the RIC. In the long term, the SEC should be able to make positive contributions to increase the quality of rural life through the activities of its members.

\section{LITERATURE REVIEW}

\section{a. Rural Entrepreneur Program (REP)}

This is a program established by the Ministry together with the private sector and RIC managers at each telecentre. The REP seeks to promote and turn rural entrepreneurs into social entrepreneurs by strengthening their economic activities and enhancing social capital. The RIC is also a major resource center for small-scale entrepreneurs to promote their local products via new media (MAMPU, 2019). Therefore, this paper focuses on social entrepreneurs' club (SEC) as one of the components of REP. Recently, the government has established an agency to advise, provide skills in know-how and assistance to rural entrepreneurs to market their products. This is a good strategy is the products are to capture local and global markets and also increase their income. The initiative is also to bridge household income gaps between urban and rural entrepreneurs. Another strategy for expanding the market and the networks is to develop smart partnerships between rural entrepreneurs and various agencies such as those in the private sectors. The government has also emphasized on attracting young entrepreneurs to get involved in rural entrepreneurship program especially in the agrofood sector (Mahathir, 2019).

According to the Ministry of Rural Development (MRD), by the year 2020, the extent of rural community involvement in entrepreneurial activities would reach a 30 percent target, as well as 
ensuring rural communities attain 100 percent ICT access and enhancing a balanced distribution of income, job opportunities, business and education for all (MRD, 2020). With the aid of technology, rural businesses can use e-commerce platforms to generate more income and increase sales revenues, e.g., rural entrepreneur platform DesaMall@KPLB. This platform has been collaborating with Shoppe, Lazada, eBay and etc. This is a government initiative and the program facilitates rural entrepreneurial activities worldwide (Shaheera, 2020).

\section{b. Economic Gardening}

The concept of 'economic gardening' was pioneered in Littleton, Colorado in 1989, with a focus on nurturing local entrepreneurs rather than "hunting and gathering" investors from outside the region (Hamilton-Pennell, 2008). The philosophy for Littleton's economic gardening program was the belief that "small local entrepreneurial firms would be the engine for the creation of sustainable wealth and new jobs, and the role of the city administration was to provide a nurturing environment within which these small firms could flourish" (Quello \& Toff, 2006).

Other states in the US that have adopted the Littleton approach, included Georgia, where a program drew upon the "lessons learned" in Littleton. Here it was found that there were benefits in having specific programs; for example: (1) access to market information (through a market research project), (2) infrastructure (through the Entrepreneur and Small Business Coordinating Network (ESBCN) and the Entrepreneur Friendly (EF) Communities initiative), and (3) connectivity (through a mentor-protégé program) (Quello \& Toff, 2006).

Thus, the SEC application of the principle of economic gardening concept as introduced in Littleton is applicable to rural entrepreneurs in Malaysia. However, its success depends on how the local entrepreneur perceived the usefulness of the approach.

\section{c. Community Informatics}

Community informatics (CI) is a technology strategy which links economic and social development efforts at the community level with emerging opportunities in areas such as telecentres. The emphasis is placed on the community as a social network, bounded by geographical location or common interest (Talbot \& Verrinder, 2005). Community informatics is also a strategy to create new patterns of usage that are community-based and emphasizes on improving life at the community level. Studies in community informatics show how the use of ICT can address the challenge of achieving economic and social development.

Community informatics focuses more specifically on the relationship between communities and information technology, and how information technology can be designed and redesigned and used for the benefit of the community (Roux, 2010). Access to and use of ICTs however, remains extremely inequitable between rural and urban areas and this is a challenge in the process of socio-economic development (Songan et al., 2004).

Simpson (2001) has introduced a community informatics initiatives framework built on physical infrastructure, soft technologies, social infrastructure and social capital. All of these components are key components in the development of telecentres and explain the need and importance of 
community informatics implementation at RICs; as well as the interplay of social capital in rural communities. The first component of a telecentre is the physical infrastructure, which includes its location, the telecommunication infrastructure and computers. The access point is where the local community/users interact with the technology and use it in diverse ways to meet differing rural community needs (Simpson, 2001). The second component is the soft technology, which includes basic ICT training, awareness programs, and ICT-related workshops based on target group categories. These activities are for the purpose of building community capacity and developing knowledge and skills to maximise the use of ICT, and to promote the community informatics initiative. The third component, social infrastructure, which in the case of the Malaysian RICs, includes a Social Entrepreneurs Club (abbreviated as SEC but better known as KUSPID), hosting events such as the RICs' Global Entrepreneurs Week program and other community service associations or networks such as BELIAWANIS (the female youth network), PUSPANITA (the women's association), RUKUN TETANGGA (the community volunteerism association). These enable individuals and groups to interact with one another and build networks. The final component, social capital, includes the intangible resources from interaction and involvement in the local community (both within RICs and outside RICs) such as forging a strong sense of community and relationships (Simpson, 2001).

\section{d. Social Capital}

Sabatini (2005) describes social capital as the norms of reciprocity within social networks by bonding similar people and creating relationships between diverse people. According to this view, social capital has three main dimensions: bonding capital, referring to strong family ties; bridging capital, referring to weaker ties among friends and acquaintances; and more formal ties linking members of voluntary organizations. Putnam $(1993,1995,2000)$ extends the concept to the community level (collective). He focuses on civil society, namely, "people's connection with the life of their community" (p. 665) and emphasizes that a community with strong associational life will demonstrate a high level of social capital, which is evident in local organizational arrangements. In addition, Fukuyama (1995) stresses the necessity of trust and the relationship between a high levels of social trust (high social capital) to high levels of economic benefits.

Woodhouse (2006) states that a community with high levels of social capital will have high levels of economic development. His study on social capital and economic development in regional Australia confirms that a town with relatively high social capital will experience a high level of economic development and vice versa. This point is supported by Lutz (2005, p. 19), who states that "social capital has a robust positive influence on income and interaction of social capital with human capital have positive impact on economic development". These positions are consistent with Fukuyama's (1999) view that a community with high levels of trust will create more social capital and achieve a high level of economic growth.

Community informatics initiatives serve to strengthen social networks and increases community/rural social capital (Williams \& Durrance, 2008). Kavanaugh et al. (2005) claim that heavy Internet users with bridging ties are more socially engaged and have more local community association since going online than those without bridging ties. Onyx and Bullen (1997) claim that social capital cannot occur in isolation by individuals but is generated in a group or community forming new associations and networks or expanding existing ones. Hence, in view of the perspective that social capital plays a role in community informatics initiatives and community 
development, participation or involvement in community activities extends social networks and leads to greater social capital.

The social capital concept in this study is understood as an outcome of accessibility, interaction and involvement networks through the RIC. The initial point is the RIC as a social network when individual users come and visit the RIC; which leads to the establishment and building of valuable relationships and networks within the rural communities and beyond. As a result of the growth of social capital, rural community members exchange and share information, build more social and business contacts, and extend their existing networks and/or create new relationships or networks.

\section{METHODOLOGY}

This study uses purposeful and random sampling as a means of attaining the smallest possible sampling error. An online survey has also been used across the 42 RIC sites to ensure that a good representative sample of valid responses were obtained. The survey, across the 42 locations, evaluates RIC users' perception of the RIC program. The actual online survey was made available via a URL link. This link was set up on the computers at RICs so that when the users logged in at one of the 42 RICs, they could access the online survey questionnaire. In addition, the sample population for this study comprises RIC users who are registered in the program across 42 RIC sites. Hence the entire population was surveyed but their participation was dependent on the RIC users visiting a RIC in their region during the period when the online survey was open (four months for the online survey data collection). The RIC managers played a critical role in ensuring the RIC users at their RIC site were aware of the online survey and encouraged RIC users at their RIC sites to participate. The RIC users were invited to participate in the online survey by posting the pop-up screen features on questionnaire at the RIC computers; thus, indirectly facilitating their participation by responding to the questionnaire (Refer Table 2). Based on the table, most of the RICs are situated in the Northern Region, comprises of 4 states representing 12 RICs. From 42 RICs, 79 percent (33 RIC sites) responded. Hence a total of 199 RIC users participated in the survey.

Table 2: RIC Site Sample and Users/Respondents' Locations

\begin{tabular}{|c|c|c|c|c|}
\hline Location by Region & Location by State & $\begin{array}{l}\text { Total no. of } \\
\text { RICs }\end{array}$ & $\begin{array}{l}\text { RIC sites with } \\
\text { responses }\end{array}$ & $\begin{array}{l}\text { RIC user } \\
\text { responses }\end{array}$ \\
\hline Northern Region & $\begin{array}{c}\text { Perlis } \\
\text { Kedah } \\
\text { Penang } \\
\text { Perak }\end{array}$ & 12 & 9 & 42 \\
\hline Eastern Region & $\begin{array}{c}\text { Kelantan } \\
\text { Terengganu } \\
\text { Pahang } \\
\end{array}$ & 7 & 7 & 65 \\
\hline Central Region & $\begin{array}{c}\text { Selangor } \\
\text { Negeri Sembilan } \\
\text { Malacca }\end{array}$ & 10 & 5 & 21 \\
\hline
\end{tabular}




\begin{tabular}{lcccc}
\hline \hline Location by Region & Location by State & $\begin{array}{c}\text { Total no. of } \\
\text { RICs }\end{array}$ & $\begin{array}{c}\text { RIC sites with } \\
\text { responses }\end{array}$ & $\begin{array}{c}\text { RIC user } \\
\text { responses }\end{array}$ \\
\hline Southern Region & Johor & 6 & 6 & 50 \\
\hline East Malaysia & $\begin{array}{c}\text { Sarawak } \\
\text { Sabah }\end{array}$ & 7 & 6 & 21 \\
\hline TOTAL & $\mathbf{1 3}$ states & $\mathbf{4 2}$ & $\begin{array}{c}\mathbf{3 3} \\
\mathbf{( 7 9 \% )}\end{array}$ & $\mathbf{1 9 9}$ \\
\hline \hline
\end{tabular}

The second phase of data collection involved face-to-face interviews and direct site observations. The interviews were means to gain deeper insights from the key program stakeholders as well as to triangulate the findings against the survey results. Thus, the interviewees were selected based on the 11 selected RIC locations. The locations were determined by four regions which are Northern (4 managers), Eastern (4 managers), Central ( 2 managers) and Southern (1 manager). The selection of interviewees was determined across four different regions and they were purposively selected. The Managers are responsible for the operational aspects of the RIC program. The regions were purposely selected based on the managers' responses to the emails sent to them. Another factor that was taken into consideration is the RIC's frequency of updating useful community information on its portal. The interviewed data were analysed using the thematic technique, whereby text was taken during interviews and later transcribed manually. The interviews transcripts, as well as other documentation, were analysed using content analysis in which key themes were identified.

\section{RESULTS AND DISCUSSION}

\subsection{RIC Social Entrepreneurs Club}

The SEC (or KUSPID in Malay) follows the principles evident in economic gardening, which is an entrepreneurial approach to economic development that seeks to enhance the growth of local economy at the local level. The objectives of the clubs are to encourage members of local communities to become entrepreneurs, to create jobs, to generate wealth and also to improve their quality of life. The four target groups of RIC users perceived the SEC and Global Entrepreneur Week (GEW) differently based on the purposes specified and whether they benefitted the target groups. However, some elderly, women, entrepreneurs and middle-aged users did not see the benefits of the SEC to them. Their main purposes of becoming SEC members and participating in the SEC and in GEW events were to gain social relationships and acquire business benefits. The clubs enabled them to participate in events that matched the target groups' needs. However, not all users or RICs were benefiting from the events conducted. This important finding is uncovered in one of the interviews with a RIC manager. Most of the RIC managers seemed uneasy towards the Social Entrepreneurs Club; thus, resulting in some ineffective SEC activities in some RIC locations and hindered the RIC's sustainability.

There were also perceptions whereby the location of the RIC itself was not strategic enough to encourage RIC users to become entrepreneurs or attract existing entrepreneurs to join the SEC because of the types of socio-economic activities in the respective areas. For example, not all areas 
of rural Malaysia have entrepreneurs, and hence for some areas the SEC was not applicable. Problems arise for RICs that do not have any entrepreneurs, especially in areas that depend more on grass-roots agriculture.

On the other hand, the SEC-RIC users' level of awareness on SEC program shows a high percentage. $69 \%$ of RIC users were aware of the existence of this club while 31 percent of RIC users were not aware (data from this study survey). Figure 1 indicates RIC users' awareness of SEC program.

Figure 1: SEC Awareness among RIC Users

\section{SEC-RIC users awareness}

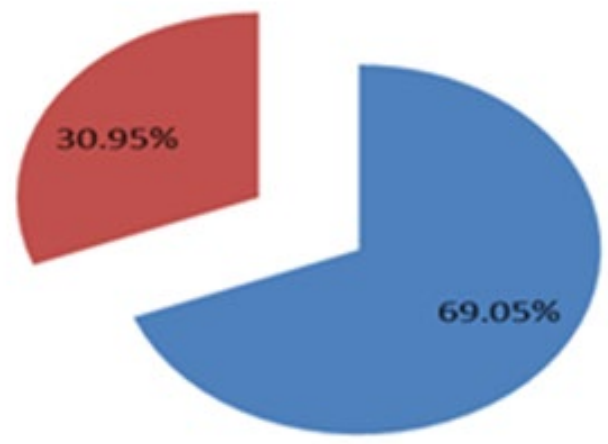

During the Global Entrepreneurship Week event, the local community also had a chance to promote their products or services to rural people. This was the opportunity for the rural community and especially the entrepreneurs to sell and promote their products. The marketing of their products would be expanded by covering wider consumers. Previously the products sold might not have been known to outside communities, however, within the RIC and through events such as the GEW, people could get to know the products. They could also make new contacts and friends as well as build or expand their business networking.

While it seems that the concept of economic gardening is applicable to the RICs' SEC, there might be a slight difference in terms of how the community perceives this approach. The culture in Malaysia, specifically in rural areas, may not be similar to the US. The rural community in Malaysia may find it quite difficult to accept entrepreneurship, and this perhaps would be something new to them. Therefore, training and workshop activities would be needed to facilitate the SEC community within the RICs to adopt the economic gardening approach to entrepreneurship activities. Most likely, the economic gardening programs are best suited to regions and states already exhibiting positive signs of entrepreneurship community building (Quello \& Toff, 2006). 
Therefore, the SEC might be attracting a reasonably high proportion of membership of the working age range, which would mean that it is actually reasonably successful in attracting attention. Thus, SEC might attract the right groups but this does not mean that it is really working at attaining its objectives.

\subsection{Business Opportunities at RICs}

Business opportunities arising from the RIC program and in particular the SEC and GEW indicate that the SEC members have become entrepreneurs and/or have expanded their businesses. The RIC and the SEC members also communicate with their customers virtually; by using the internet. Thus, these key findings reaffirm existing literature on telecentres and business opportunities. The SEC has not only motivated rural communities to use the RIC, but also enables them to seek more social and business contacts. This key finding is in line with those of previous studies on telecentres that were built around users' connection (Raul \& Colle, 2002).

Figure 2 provides perception of business opportunities at RIC and/or at SEC. The SEC is also meant to provide business opportunities for RIC users and/or SEC members in entrepreneurship. The online survey results regarding business opportunities arising from SEC are shown in Figure 2 .

Figure 2: Perceived Benefits (SEC) of SEC Member

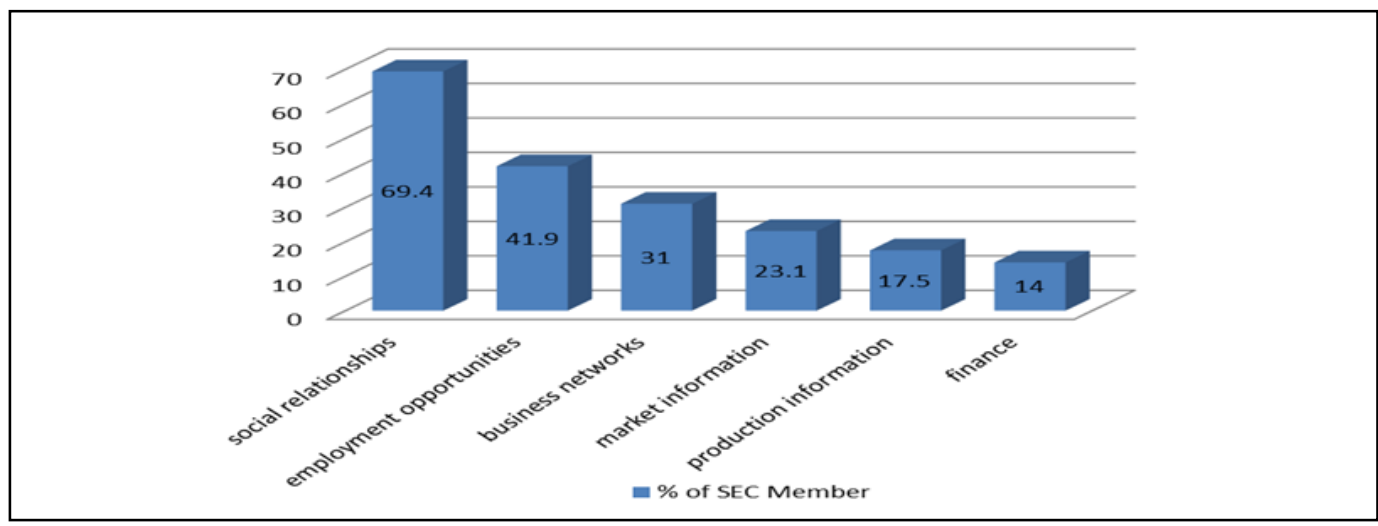

For instance, the Global Entrepreneurs Week event brought many entrepreneurs to the SEC and RICs. The entrepreneurs generated ideas and networks and also moved together with the local community. With the implementation of the SEC, and the perspective of the role that social capital plays in community informatics initiatives and community development, participation or involvement in community activities extends social networks and leads to greater social capital. Hence, this describes the concept of bonding and bridging capital, as well as local community association at the RICs. Related to this research, the RIC is also an example of bonding ties within the RIC, or bridging ties that formed a bridge between communities. According to social network theory, "weak social ties are generally thought to bring new information (information that led to a new job), strong ties to bring social support" (Williams, 2005). This study reaffirms the statement 
that the RIC builds social capital and also creates employment opportunities for rural communities. In addition, the RIC has also become a social support to the RIC users. Thus the researchers believe that the concept of community informatics in RICs has the potential to build both bridging and bonding capital in rural communities.

\subsection{Job Opportunities at RICs}

In relation to employment, teleworking can be introduced at RICs as a means to achieve sufficient income to maintain services. As it is easy for telecentres in rural areas to fall behind on current ICT usage and business practices, it should be emphasised that the SEC's business feature must facilitate RIC users to become new entrepreneurs. Bertin (2001, p.183) explains the features of teleworking as follows:

First, teleworking is working at a distance from the people who pay you, either at home, on the road or at a locally based centre. Teleworkers use e-mail, phone and fax to keep in touch with their employers or customers. Teleworking is part of a range of flexible work practices that are becoming widespread and also include flexible time as well as working part-time.

Second, teleworking could also provide jobs to people after completing ICT training programs at a RIC. Bertin (2001) claims that many telecentres generated most of their income in exchange for providing ICT training courses to the users or trainees. Teleworking could also inspire the RICs to act as multi-purpose providers of services and information for their local communities. The local community members could be made aware of the opportunities and be paid for jobs performed. As a consequence of teleworking, creating continuous training services are relevant especially to remote rural areas; if there is no continuing market for the training, the RICs will eventually run out of trainees or users and will close down. This is supported by the example of one of the longestsurviving telecentres in the UK, Moorlands Telecottage, which used to provide telework opportunities to trainees. In that example, local government and other funding bodies provided assistance with training telecentre users. In return, the trainees would gain a greater variety of training and learn a variety of skills for different work tasks (Bertin, 2001).

\subsection{Social Capital at RICs}

One of the participant program managers noted that through the SEC's Global Entrepreneurship Week, RICs' users who were members of the SEC increased their external contacts from telecentres worldwide. With the use of Web 2.0 applications (Face book, email, blogging, Twitter) as platforms, RIC users were communicating through the RIC indirectly and were able to share their experiences. They could also get advice from entrepreneurs at the other RICs. As a result, the RICs also communicated with one another through Face book presence. Therefore, the RICs had connected with each other through the application at the respective RICs:

... Via GEW event...RIC also got contacts from other telecentres and from other countries...RIC itself communicates and has the Face book platform... communicate with the other RICs, they are communicating through the RIC, indirectly, the RIC had connected the entrepreneurs. [WG Officer] 
Another participant program manager claimed:

... Through SEC and RIC, the users create networks... business networking and social relationships. [Management Committee 3]

Once they got contacts...they complement each other...before this, their networking is not that strong, but once they joined RIC...particularly SEC; they have strong network. [Southern Manager]

The RIC Social Entrepreneurs Club initiative is an attempt to encourage the local community to get involved in entrepreneurship and socialised within the environment. The focus of the initiative is to encourage people to start and expand their businesses and also at the same time, build social networking and relationships. At the RIC and SEC, this is translated into social capital. The people were connected and made contacts through the RIC and indirectly, the SEC. The RIC and SEC have been able to generate social entrepreneurs and social capital; thus, increasing local community's participation and RIC's generation of benefits.

\section{CONCLUSION}

This research has shown that the RIC is able to improve community capacity building with the use of ICT applications and broadband initiatives, through training and information system development. By adopting a comprehensive theoretical framework drawn from community informatics on community development and social capital theories to evaluate the RIC program, it is shown that social capital can be generated and strengthened among entrepreneurs through social networking applications. This is a new empirical contribution to the growing literature on community informatics and social capital; as opposed to the majority of previous sociological studies on social capital. It is important to note that ICT has not been particularly well understood in terms of the contributions made in the context of community informatics and social capital in telecentres. This is exemplified by the rural Malaysia telecentres. Hence it is argued that the findings of this research can be implemented in other similar rural communities in the quest to promote the number of rural entrepreneurs.

Unlike previous studies on telecentres that emphasized on the impact of ICT in developing countries, this research analyzed rural entrepreneur activity in RICs, by focusing on SEC through the theoretical lens of community informatics and social capital. This research proves that the community informatics contribute to the improvement in social capital and economic benefits, as well as entrepreneurship. In fact, the expected results from these key findings might be similar to other studies on the association of social capital with economic benefits. In addition, it can also be learnt that the RIC management and the Ministry are the crucial stakeholders involved and responsible for the whole process of RIC. Any changes made by the management and the Ministry will be affected to RIC program or system. Therefore, to sustain the RIC and particularly the SEC, this suggests that with an injection of sufficient funds, human capital with continuous support from the Ministry as well as the required technology, then the RIC will have more chances to grow and be sustainable. 


\section{ACKNOWLEDGEMENTS}

The authors wish to extend thanks to the Ministry involved for the commitment and cooperation to provide data and relevant information for this paper. And also special thanks to the senior RIC program officers, RIC managers, RIC users, non-RIC users, RIC committee members and local communities involved directly or indirectly with this research.

\section{REFERENCES}

Bertin, I. (2001). Teleworking and Telecentres. Chapter 17. Perspectives on Distance Education Telecentres: Case studies and key issues. The Commonwealth of Learning, Vancouver, 2001

Fukuyama, F. (1995). Trust: Social Virtues and the Creation of Prosperity. New York, Free Press. Fukuyama, F. (1999). The Great Disruption: Human Nature and the Reconstitution of Social Order. New York: Free Press.

FOMCA. (2019). Pusat Internet Desa (PID) seluruh negara akan ditambah baik- Timbalan Menteri Komunikasi dan Multimedia Malaysia. Retrieved from http://www.fomca.org.my/v1/index.php/fomca-di-pentas-media/302-pusat-internetdesa-pid seluruh-negara-akan-ditambah-baik-timbalan-menteri-komunikasi-danmultimedia-malaysia

Hamilton-Pennell, C. (2008). Growing Local Economies. Economic Gardening.

Kavanaugh, A. L., Reese, D. D., Carroll, J. M. \& Rosson, M. B. (2005). Weak ties in networked communities. The Information Society, 21, 119-131.

Lutz, M. B. (2005). Institutions, social capital and economic development in africa: an empirical study. International Centre for Economic Research, ICER.

MAMPU (2019). Rural internet center / Telecentres (pid). MyGovernment. Retrieved from https://www.malaysia.gov.my/portal/content/30631

Marhaini, M. N. (2010). Assessing the impacts of rural internet center programs on quality of life in rural areas of Malaysia. International Conference on ICT for Development 2010, Postgraduate Strand. 13 December 2010 at Royal Holloway, University of London.

Mahathir, M. (2019, October 19). Government to establish agency to help market products of rural entrepreneurs. Malay Mail. Retrieved from https://www.malaymail.com/news/malaysia/2019/10/19/govt-to-establish-agency-tohelp-market-products-of-rural-entrepreneurs/1801787

MCMM. (2019, April 16). KKMM lancar pelan strategik bagi tempoh lima tahun. Sinar Harian. Retrieved from https://www.sinarharian.com.my/article/23747/BERITA/Nasional/KKMM-lancarpelan-strategik-bagi-tempoh-lima-tahun

MEWC (2006). Pusat Internet Desa (RIC) Introduction: Brief [Online]. Retrieved from http://www.ktak.gov.my.

MRD (2020). Ministry of rural development-official portal. Profile objective. Retrieved from http://www.rurallink.gov.my/en/corporate-info/profile/objective/

MRRD (2010). Challenges in bringing ICT to the rural communities: Transforming rural community towards K-society. ASEAN Short Course 2010, 27th - 29th September 2010 2010 Kuala Lumpur, Malaysia. ASEAN Secretariat. 
Onyx, J. \& Bullen, P. (1997). Measuring social capital in five communities in NSW. A Practitioner's Guide. Coogee, Australia: Management Alternatives Pty. Ltd.

Putnam, R. D. (1993). The prosperous community. American Prospect.

Putnam, R. D. (1995). Tuning in, tuning out: The strange disappearance of social capital in America. Political Science and Politics, 28(4), 664-683

Putnam, R. (2000). Bowling Alone: The collapse and revival of American community, New York.

Quello, S. \& Toff, G. (2006). "Economic Gardening: next generation applications for a balanced portfolio approach to economic growth". The small business economy. December 2006 ed.: United States Small Business Administration.

Raul, R. \& Colle, R. D. (2002). Themes and issues in telecentre sustainability. Development Informatics. Manchester, UK: Institute for Development Policy and Management, University of Manchester, UK.

Roux, L. C. J. B. (2010). Social informatics vs. community informatics: A brief overview of their origins and current status. Mousaion. Retrieved from http://www.sabinet.co.za/abstracts/mousaion/mousaion_v28_n1_a3.html.

Sabatini, F. (2005). The empirics of social capital \& economic development: A critical perspective. FEEM Working Paper No. 15.2006

Simpson, L. (2001). Community informatics and sustainability: Why social capital matters. The Journal of Community Informatics, 1(2), 1-20.

Songan, P., Hamid, K. A, Yeo, A., Gnaniah, J. \& Zen, H. (2004). Community Informatics: Challenges in Bridging the Digital Divide. Kuala Lumpur.

Talbot, L. \& Verrinder, G. (2005). Promoting health: The primary health care approach. Elsevier Australia.

Shaheera, A. S. (2020, January 29). Rural entrepreneur platform DesaMall@KPLB eyes RM2.5m sales in 2020. The Malaysian Reserve. Retrieved from https://themalaysianreserve.com/ 2020/01/29/rural-entrepreneur-platform-desamallkplb-eyes-rm2-5m-sales-in-2020/

Williams, K. H. (2005). Telecentres and the provision of community-based access to electronic information in everyday life.

Williams, K. \& Durrance, J. C. (2008). Social networks and social capital: Rethinking theory in community informatics. The Journal of Community Informatics, 4(3), 1-20.

Woodhouse, A. (2006). Social capital and economic development in regional Australia: A case study. Journal of Rural Studies, 22(1), 83-94. 